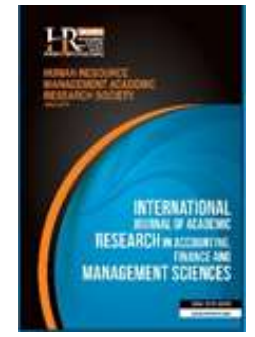

International Journal of Academic Research in Accounting, Finance and Management Sciences

Vol. 10, No.2, April 2020, pp. 1-8

E-ISSN: 2225-8329, P-ISSN: 2308-0337

(c) 2020 HRMARS

www.hrmars.com

To cite this article: Tarmidi, D., Sari, P. N., Handayani, R. (2020). Tax Avoidance: Impact of Financial and NonFinancial Factors, International Journal of Academic Research in Accounting, Finance and Management Sciences 10 (2): 1-8.

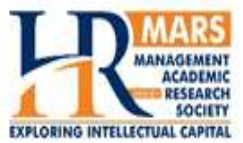

http://dx.doi.org/10.6007/IJARAFMS/v10-i2/7238

(DOI: 10.6007/IJARAFMS/v10-i2/7238)

\title{
Tax Avoidance: Impact of Financial and Non-Financial Factors
}

\author{
Deden Tarmidi ${ }^{1}$, Pratiwi Nila Sari ${ }^{2}$, Riaty Handayani ${ }^{3}$ \\ ${ }^{1}$ Universitas Mercu Buana, Jakarta, Indonesia, ${ }^{1}$ E-mail: deden.tarmidi@mercubuana.ac.id (Corresponding author) \\ ${ }^{2}$ Universitas Bhayangkara Jakarta Raya, Jakarta, Indonesia
}

\begin{abstract}
This study is a follow-up study of research on tax avoidance that has been conducted by researchers and also as a confirmatory study of the results of existing studies with the same topic, namely tax avoidance. The fact that tax revenue in Indonesia has not reached the target so far and the level of tax compliance that is less than optimal in Indonesia encourages researchers to analyze the factors that influence it. The fact is that even though taxes are used for the benefit of the general public and are managed by the state, for companies as corporate taxpayers that taxes are a burden that can reduce profits and management performance, so companies generally avoid tax to minimize the tax burden. As an organization, company management policies are influenced by many factors, both internal and external factors, both on the basis of financial and non-financial conditions, including policies in tax avoidance. Adopting previous studies, some of the financial factors analyzed in this study are Company Profitability and Size while the non-financial factors analyzed are Independent Commissioners and Institutional Ownership. The results found that profitability and company size had a negative effect on Tax Avoidance while independent commissioners had a positive effect. In the sensitivity test it is known that the level of influence of financial factors and non-financial factors has the same impact on tax avoidance actions.
\end{abstract}

Key words

Tax Avoidance, Profitability, Size, Independent Commissioners, Institutional Ownership.

Received: 18 Mar $2020 \quad$ (c) The Authors 2020

Revised: 20 Apr 2020 Published by Human Resource Management Academic Research Society (www.hrmars.com)

Accepted: $\quad 30$ Apr 2020 This article is published under the Creative Commons Attribution (CC BY 4.0) license. Anyone may reproduce, distribute, translate and create derivative works of this article (for both commercial and non-commercial purposes), subject to full attribution to the original publication and authors. The full terms of this license may be seen at: http://creativecommons.org/licences/by/4.0/legalcode

\section{Introduction}

Tax revenue has an important role for the development of a country, especially for developing countries like Indonesia. Then the regulator needs to analyze all the factors that have a relationship with tax revenue to then be the basis in making policies so that the realization of revenue in accordance with the specified targets. Although various policies have been taken by the Directorate General of Taxes as the authorities in Indonesia, state revenue from year to year is always far from the target set by the Government.

Although the provisions state that taxes are used for the benefit of the general public and are managed by the Government, but for companies that taxes are one of the burdens that reduce corporate profits so they must be minimized so that they do not have further negative impacts on both internal management and on investors as external parties. This is the root of the problem of the tax revenue target that has never been reached. One way to minimize the tax burden is by avoiding taxes or tax avoidance, which is an active resistance of taxpayers to tax authorities in avoiding taxes (Pohan, 2013). 
In contrast to acts of tax evasion that clearly violate the provisions, the act of tax avoidance is in fact no provision is violated because this action exploits loopholes or opportunities in minimizing tax burdens that are not clearly prohibited in the tax provisions (Ngadiman et al., 2014; Mardiasmo, 2016).

Several cases of tax avoidance are often reported by domestic and foreign media, one of which is the case of PT. Bentoel Internasional Investama, a subsidiary of British American Tobaco (BAT) which avoids taxes by paying loan interest, royalties, fees and IT costs to the group of companies (Kontan.co.id). The fact is that in the applicable tax provisions there are no restrictions on paying loan interest, royalties, fees and IT fees made by taxpayers, especially those related to taxpayer's business activities, but because the payment of these costs is done to companies that are still 1 group the amount is considered reasonable and results in reduced tax payments and certainly has the potential for tax evasion.

One of the reasons for taxpayers to take tax avoidance actions is a predetermined profit target and a desire to add taxpayer assets so that even though profits and assets are high, tax avoidance actions will continue to be high. But there are also taxpayers who reduce tax avoidance when assets and profits are already high; this is because taxpayers already feel prosperity so they voluntarily pay taxes according to applicable regulations.

Puspita (2014) in his research found that profitability had a positive effect on tax avoidance, while the opposite results were found Wiratmoko (2018), Hidayat (2018), and Ariawan (2017) who found that the level of profitability had a negative effect on tax avoidance. In other studies, Irianto (2017) and Diantari (2016) found a positive effect on firm size on tax avoidance, but Setiawan (2016) and Maharani (2014) found a negative effect on firm size on tax avoidance.

Tax avoidance is one of the management activities in displaying good performance so that Good Corporate Governance is needed to minimize these actions because it has the risk of future tax penalties that will reduce the company's assets. Independent commissioners and institutional ownership are part of corporate governance that has a function in overseeing management actions, including tax avoidance. The higher the number of independent commissioners, the more parties are overseeing the actions of internal management, so that management will be wiser in taking tax avoidance actions and even avoiding them. This is also the case with institutional ownership, where a high level of institutional ownership causes higher investor oversight of management so that management is more careful in taking action, including tax avoidance.

Wijayanti (2017) and Diantari (2016) found that independent commissioners had a negative effect on tax avoidance, but Eksandy (2017) and Subagiastra (2016) in their research found the opposite where independent commissioners had a positive effect on tax avoidance. In line with the study of Murni (2018) and Pattisana (2019) found that Institutional ownership has a positive influence on tax avoidance even though research by Cahyono (2016) and Setiawan (2016) found the opposite that institutional ownership has a negative impact on tax avoidance.

Based on the background above and the research gap found in previous studies, researchers are interested in conducting a repeat study to confirm the influence of financial factors such as profitability and company size and non-financial factors such as independent commissioners and institutional ownership in manufacturing companies listed on the Indonesia Stock Exchange period 2014-2018.

Strengths of this study are the additional comparative analysis between financial and non-financial factors of the entity and their impact on tax evasion. This analysis is needed so that regulators can take appropriate policies in dealing with taxpayers who take tax avoidance actions.

\section{Literature review}

\subsection{Stakeholders theory}

Stakeholder Theory is a theory which states that a company is not an entity that only operates for its own interests, but must provide benefits to all its stakeholders including shareholders, creditors, consumers, suppliers, governments, communities, analysts, and other parties (Ghazali \& Chariri; 2007: 409). It is this stakeholder group that is taken into consideration by company management in disclosing or not providing information in the company's report. The main purpose of stakeholder theory is to assist company management in increasing value creation as a result of the activities carried out and minimizing losses that may arise for stakeholders. The above theory asserts that financial reporting is one way to 
manage the trust of stakeholders, where the presence of stakeholders will greatly affect the mindset and management's perception of the urgency of corporate accounting practices. Stakeholders can influence or be influenced by companies both directly and indirectly (Tarmidi, 2019). To maintain its survival, the company must maintain good relations with stakeholders, because stakeholders have influence on the company's operations (Tarmidi et al., 2019). Thus, companies cannot escape from the role of stakeholders.

In this study, the influence of financial and non-financial factors on tax avoidance is analyzed, where the non-financial factors analyzed are independent commissioners and institutional ownership. As an outside party, an independent commissioner is a company stakeholder whose job is to oversee every company's actions so as not to harm the company in the future. Likewise with outside institutions which are company owners are also one of the stakeholders who have the expectation of return on the entity's business activities.

\subsection{Conceptual Framework and Hypothesis Development}

The company as a profit-oriented organization certainly has a goal to seek profit as much as possible and because the tax is an expense that will reduce the company's profit, the company will take action to minimize it. Even so, companies will be more careful in making policies to minimize the tax burden so that tax avoidance measures will be preferred over tax evasion actions. Because of this, the level of profitability of the company will not reduce the company's policy in minimizing the tax burden, but instead it will be higher so that the level of profitability is even higher in the future or it will even reduce the level of tax avoidance because it feels the company has prospered. In line with Puspita's research (2014), Wiratmoko (2018), Hidayat (2018), and Ariawan (2017) which found that corporate profitability affected tax avoidance.

\section{H1. Profitability affects tax avoidance}

In line with the level of profitability, the company as a profit-oriented organization also has a goal to enlarge the company and live longer. This is reflected that even though the size of the company is already large, tax avoidance measures continue to be carried out so that the size of the company is even greater in the future so that business sustainability will be even longer. Conversely, companies that feel already prosperous or wealthy are expected to be more compliant with applicable regulations so that they do not take actions that can harm the company in the future. In line with research by Irianto (2017), Waluyo (2017), Diantari (2016), Setiawan (2016) and Maharani (2014) which found that company size affects the tax avoidance.

\section{H2. Company size affects tax avoidance.}

In non-financial factors, the independent commissioner has an important role in the supervision and control of the company so as not to adopt policies that are not in line with the company's objectives and applicable provisions so as not to harm the company. Although tax avoidance does not violate the tax rules, the risk of future tax penalties for harming the country encourages independent commissioners to control companies in minimizing tax avoidance. In addition, as a profit-oriented entity, the commissioner has the task for management to take action according to the company's goals and targets in maximizing profits so as to encourage management to take any action including tax avoidance. In line with Ariawan's (2017) research, Diantari (2016), Wijayanti (2017), Wiratmoko (2018), Eksandy (2017), Waluyo (2017) and Subagiastra (2016).found that independent commissioners had an effect on tax avoidance.

\section{H3. Independent Commissioners influence tax avoidance}

In line with the independent commissioners, institutional ownership also has an important role in the supervision and control of the company so as not to take policies that are not in line with the company's objectives and applicable provisions so as not to harm the company. Fellow institutions, institutional shareholders understand that the tax audit process does not only occur due to acts of tax evasion that are clearly in conflict with the tax provisions but can also occur in tax avoidance so that the risk of future tax penalties remains. Conversely, as an institution that also has a profit orientation, ownership institutions encourage management to maximize profits in any way including tax avoidance measures. To some extent institutional ownership is thought to encourage companies in tax avoidance. In line with Jamie's (2017) 
research, Setiawan (2016), Subagiastra (2016) and Cahyono (2016) who find that institutional ownership negatively influences tax avoidance measures.

H4. Institutional ownership influences tax avoidance.

\section{Methodology of research}

\subsection{Population and sample}

The population of this research is manufacturing companies listed on the Indonesia Stock Exchange in the period 2013 - 2018. The sample selection is done by purposive sampling method with the following criteria: (1) Manufacturing companies listed on the Indonesia Stock Exchange in 2013-2018, (2) have financial statements fully published for 5 years (2013-2018), (3) Has complete analytical data on published reports. Of the 144 manufacturing companies listed on the Indonesia Stock Exchange as a population, there are 26 companies sampled because they have a Tax Avoidance value or have an ETR value below the tax rate for 5 years of observation, so the data processed is 130 data.

\subsection{Operational variable}

The Tax Avoidance variable is the dependent variable in this study. Tax avoidance is an effort of taxpayers to minimize the tax burden legally (Pohan, 2013). Adopting Jamei research (2017), tax avoidance in this study is measured by reducing Statutory Rate Tax with Actual Rate Tax. As an independent variable, the measurement of each variable adopts the measurement of variables that have been used in subsequent studies. Profitability in this study was measured using ROE, while company size was measured using LogTotal Assets as used by Cahyono (2016). Adopting Arry (2017), independent commissioners are measured by dividing the number of independent commissioners by the total commissioners. While institutional ownership is measured by dividing the number of institutional shares by the number of shares as used in research Cahyono (2016).

\subsection{Hypothesis testing method}

Data analysis was performed with the help of STATA software with several stages such as the selection of models and classical assumptions to then be analyzed the results of the overall regression and sensitivity test by comparing the regression of financial factors and non-financial factors regression of tax avoidance measures.

\section{Results}

\subsection{Descriptive Analysis}

Table 1. Descriptive analysis

\begin{tabular}{lccc}
\hline \multicolumn{1}{c}{ Variable } & Min & Max & Mean \\
\hline Y. Tax Avoidance & 0.0053 & 3.7310 & 0.2140 \\
X1. Profitability & -2.9592 & 2.3502 & 0.0215 \\
X2. Size & 3.8835 & 8.5375 & 6.4449 \\
X3. Independent Commissioner & 0.0000 & 0.6667 & 0.3908 \\
X4. Institutional Ownership & 0.4770 & 0.9896 & 0.7291 \\
\hline
\end{tabular}

\subsection{Hypothesis Test}

Before testing the hypothesis, a classic assumption test is done in the form of normality, multicollinearity, heteroscedasticity and autocorrelation tests. Abnormal data are generated at the beginning with a sign value of 0,000 or below the significance value of 0.05 , then winsorizing is done so that the resulting sign value is 0.147 and becomes normal because it is above the significance value of 0.05 . In the multicollinearity test, all vif values below 10 , in the heteroscedasticity test Prob> chi2 data was 0.3387 , while the autocorrelation test contained Prob> F data of 0.5743 so that the research data was free from the assumptions of multicollinearity, heteroscedasticity and autocorrelation data. 
Table 2. Hypothesis Test

\begin{tabular}{|l|c|c|}
\hline \multicolumn{1}{|c|}{ Variable } & Coef. & P>(t) \\
\hline Profitability (X1) & -0.03577 & $0.015^{* *}$ \\
\hline Size (X2) & -0.01894 & $0.081^{*}$ \\
\hline Independent Commissioner (X3) & 0.18338 & $0.0199^{* *}$ \\
\hline Institutional Ownership (X4) & -0.03094 & 0.610 \\
\hline $\mathrm{N}$ & \\
\hline R-Square & \\
\hline Prob F & \multicolumn{2}{l|}{} \\
\hline
\end{tabular}

Note: $*$ Significant $10 \%, * *$ Significant $5 \%, * * *$ Significant $1 \%$

From table 2 it is known that Hypothesis 1, Hypothesis 2 and Hypothesis 3 are accepted while Hypothesis 4 is rejected. With a negative and significant coefficient value below 0.05 , it can be explained that profitability has a negative effect on Tax Avoidance. This means that the greater the profitability of an entity, the level of Tax Avoidance will decrease. As a profit-oriented company of course the company does everything to achieve the profit target to do tax avoidance, but with the achievement of the desired target the tax avoidance also decreases. The results of this study are in line with research by Wiratmoko (2018), Hidayat (2018), and Ariawan (2017). With a negative and significant coefficient value below 0.10 it can be explained that the size of the company has a negative effect on tax avoidance. This means that the greater the assets owned by the company, the level of tax avoidance will decrease. Asset is defined as a symbol of the prosperity of an entity, so that when a company is considered prosperous and rich enough, the company will be more obedient to the tax provisions and the level of tax avoidance gets smaller. This is in line with research by Setiawan (2016) and Maharani (2014).

Independent commissioner value has a positive and significant coefficient below 0.05 , it can be explained that the more independent commissioners, the higher the level of tax avoidance. Although the commissioner's job is to oversee management in managing the business, in this case the function is more to the objectives of the entity namely profits and business targets. So with the number of independent commissioners, the management would do more tax avoidance to maximize company profits. This is in line with research by Eksandy (2017) and Subagiastra (2016).

Table 3. Impact of financial and non-financial factors on entity-s tax avoidance

\begin{tabular}{|c|c|c|c|c|c|c|}
\hline \multirow{2}{*}{ Variable } & \multicolumn{3}{|c|}{ Financial Factors } & \multicolumn{3}{|c|}{ Non-Financial Factors } \\
\hline & Coef. & P> & & Coef. & $P>(t$ & \\
\hline Profitability (X1) & -0.03690 & 0.013 & ** & & & \\
\hline Size (X2) & -0.01737 & 0.089 & * & & & \\
\hline Independent Commissioners (X3) & & & & 0.19159 & 0.018 & ** \\
\hline Institutional Ownership (X4) & & & & 0.01029 & 0.859 & \\
\hline $\mathrm{N}$ & 130 & & & 130 & & \\
\hline R-Square & 0.0766 & & & 0.0438 & & \\
\hline Prob F & 0.0621 & & * & 0.0581 & & * \\
\hline
\end{tabular}

Note: * Significant $10 \%,{ }^{* *}$ Significant $5 \%, * * *$ Significant $1 \%$

With the $F$ value of each group below the significance level of 0.10 in table 3 it explains that financial factors and non-financial factors have the same impact on an entity's tax avoidance. Financial factors together have a significant impact with a level below 0.10 with a negative coefficient value meaning that the higher the financial factors of a company, the level of tax avoidance will decrease. This explains that economic or especially financial factors are the things that underlie companies in taking tax avoidance actions. Conversely, although non-financial factors have the same significance with a level below 0.10 , with a positive coefficient value explains that the higher the non-financial factors of a company, the level of tax avoidance will increase. This explains that the pressure and supervision from external companies, both independent commissioners and institutional ownership, encourage management to act seriously in maximizing corporate profits, with one way to do is tax avoidance. 


\section{Conclusions}

This study found the following results:

a. Profitability has a negative effect on tax avoidance;

b. Size has a negative effect on tax avoidance;

c. Independent commissioners have a positive effect on tax avoidance;

d. Institutional Ownership has no significant effect on tax avoidance.

\section{Implication and Limitation}

The results of this study can provide input to investors or the public in assessing entities from the level of tax avoidance carried out in order to measure future compliance costs. The level of profitability, size and independent commissioners can be used as a measure in predicting companies in carrying out tax avoidance. The results of this study did not find the effect of institutional ownership, it is hoped that further research can use other variables in analyzing entity's tax avoidance. This study also only uses 130 data from 26 companies while the population owned is 144 companies so these results may not represent the study population.

\section{Acknowledgment}

This study supported by the Faculty of Economic and Business and Research Center of Universitas Mercu Buana and Universitas Bhayangkara Jakarta Raya, we are grateful for the supported from Dean, Rector, Research Center team.

\section{References}

1. Arianandini, P. W., \& Ramantha, I. W. (2018). Pengaruh Profitabilitas, Leverage, dan Kepemilikan Institusional pada Tax Avoidance. E-Jurnal Akuntansi Universitas Udayana, 22(3), pp. 2088-2116.

2. Ariawan, I. M. A. R., \& Setiawan, P. E. (2017). Pengaruh Dewah Komisaris Independen, Kepemilikan Instistusional, Profitabilitas dan Leverage Terhadap Tax Avoidance. (2017). E-Jurnal Akuntansi Universitas Udayana, 18(3), pp. 1831-1859

3. Cahyono, D. D., Andini, R., \& Raharjo, K. (2016). Pengaruh Komite Audit, Kepemilikan Institusional, Dewan Komisaris, Ukuran Perusahaan (Size), Leverage (DER), dan Profitabilitas (ROA) terhadap Tindakan Penghindaran Pajak (Tax Avoidance) pada Perusahaan Perbankan yang Listing BEI Periode Tahun 20112013. Journal of Accounting, 2(2), pp. 1-10.

4. Dewi, N. N. K., \& Jati, I. K. (2014). Pengaruh Karakter Eksekutif, Karakteristik Perusahaan, dan Dimensi Tata Kelola Perusahaan yang Baik pada Tax Avoidance di Bursa Efek Indonesia. E-Jurnal Akuntansi Universitas Udayana, 6(2), pp. 249-260.

5. Diantari, P. R., \& Ulupui, I. A. (2016). Pengaruh Komite Audit, Proporsi Komisaris Independen, dan Proporsi Kepemilikan Institusional terhadap Tax Avoidance. E-Jurnal Akuntansi Universitas Udayana, 16(1), pp. 702-732.

6. Eksandy, A. (2017). Pengaruh Komisaris Independen, Komite Audit, dan Kualitas Audit terhadap Penghindaran Pajak (Tax Avoidance) (Studi Empiris pada Sektor Industri Barang Konsumsi yang terdaftar di Bursa Efek Indonesia Periode 2010-2014. Competitive, 1(1), pp. 1-20.

7. Fiandri, K. A., \& Muid, D. (2017). Pengaruh Kepemilikan Institusional dan Ukuran Perusahaan terhadap Tax Avoidance dengan Kinerja Keuangan sebagai variable Mediasi pada Perusahaan Manufaktur yang Terdaftar di Bursa Efek Indonesia Tahun 2011-2014. Diponegoro Journal of Accounting, 6(2), pp. 1-13.

8. Hidayat, W. W. (2018). Pengaruh Profitabilitas, Leverage, dan Pertumbuhan Penjualan Terhadap Penghindaran Pajak: Studi Kasus Perusahaan Manufaktur Indonesia. Jurnal Riset Manajemen dan Bisnis, 3(1), pp. 19-26.

9. Irianto, B. S., Sudibyo, Y. A., \& Wafirli, A. (2017). The Influence of Profitability, Leverage, Firm Size and Capital Intensity towards Tax Avoidance. International Journal of Accounting and Taxation, 5(2), pp. 3341. 
10.Jamei, R. (2017). Tax Avoidance and Corporate Governance Mechanism: Evidence from Tehran Stock Exchange. International Journal of Economics and Financial, 7(4), pp. 638-644.

11.Khairunisa, K., Hapsari, D. W., \& Aminah, W. (2017). Kualitas Audit, Corporate Social Responsibility, dan Ukuran Perusahaan Terhadap Tax Avoidance. Jurnal Riset Akuntansi Kontemporer, 9(1), pp. 39-46.

12.Maharani, I. G. A. C., \& Suardana, K. A. (2014). Pengaruh Corporate Governance, Profitabilitas dan Karakteristik Eksekutif pada Tax Avoidance Perusahaan Manufaktur. E-Jurnal Akuntansi Universitas Udayana, 9(2), pp. 525-539.

13.Merslythalia, R., \& Lasmana, M. S. (2016). Pengaruh Kompetensi Eksekutif, Ukuran Perusahaan, Komisaris Independen, dan Kepemilikan Institusional terhadap Tax Avoidance. Jurnal IImiah Akuntansi dan Bisnis, 11(2), pp. 117-124. https://doi.org/10.24843/JIAB.2016.v11.i02.p07.

14.Murni, Y., Sudarmaji, E., \& Sugihyanti, E. (2016). The Role of Institutional Ownerships, Board of Independent Commissioner and Leverage: Corporate Tax Avoidance in Indonesia. IOSR Journal of Business and Management, 18(11), pp. 79-85.

15.Oktamawati, M. (2017). Pengaruh Karakter Eksekutif, Komite Audit, Ukuran Perusahaan, Leverage, Pertumbuhan Penjualan, dan Profitabilitas terhadap Tax Avoidance. Jurnal Akuntansi Bisnis, 15(1), pp. 23-40.

16.Oktaviyani, R., \& Munandar, A. (2017). Effect of Solvency, Sales Growth, and Institutional Ownership on Tax Avoidance with Profitability as Moderating Variables in Indonesian Property and Real Estate Companies. Binus Business Review, 8(3), pp. 183-188.

17.Pattiasina, V., Tammubua, M. H., Numberi, A., Patiran, A., \& Temalagi, S. (2019). Capotal Intensity and Tax Avoidance: A Case of Indonesia. International Journal of Social Science and Humanities, 3(1), pp. 58-71.

18.Puspita, S. R., \& Harto, P. (2014). Pengaruh Tata Kelola Perusahaan terhadap Penghindaran Pajak. Diponegoro Journal of Accounting, 3(2), pp. 1-13.

19.Reinaldo, R., Zirmal., \& Rusli. (2017). Pengaruh Leverage, Ukuran Perusahaan, ROA, Kepemilikan Institusional, Kompensasi Kerugian Fiskal, dan CSR terhadap Tax Avoidance pada Perusahaan Manufaktur Subsektor Makanan dan Minuman Terdaftar di BEI 2013-2015. Jurnal Online Mahasiswa, 4(1), pp. 45-59.

20.Sandra, M. Y. D., \& Anwar, A. S. H. (2018). Pengaruh Corporate Social Responsibility dan Capital Intensity terhadap Penggelapan Pajak (Studi Empiris pada Perusahaan Pertambangan yang terdaftar di BEI). Jurnal Akademi Akuntansi, 1(1), pp. 1-10.

21.Setiawan, A., \& Al-Ahsan, M. K. (2016). Pengaruh Size, Leverage, Profitability, Komite Audit, Komisaris Independen dan Investor Konstitusional terhadap Effective Tax Rate (ETR). Jurnal EKA CIDA, 1(2), pp. 1-16.

22.Subagiastra, K., Arizona, I. P. E., \& Mahaputra, I. N. K. A. (2016). Pengaruh Profitabilitas, Kepemilikan Keluarga, dan Good Corporate Governance terhadap Penghindaran Pajak. Jurnal Ilmiah Akuntansi, 1(2), pp. 167-193.

23.Sunarsih, U., \& Oktaviani, K. (2016). Good Corporate Governance in Manufacturing Companies Tax Avoidance. Etikonomi, 15(2), pp. 85-96.

24.Susanto, L., Yanti., \& Viriany. (2018). Faktor-faktor yang Mempengaruhi Agresivitas Pajak. Jurnal Ekonomi, XXIII(1), pp. 10-19.

25.Tarmidi, D. (2019). Tax Compliance and Uncompliance Entity: A Comparative Study of Investor Reaction. International Journal of Academic Research in Accounting, Finance and Management Sciences, 9 (1): 105-110.DOI:10.6007/IJARAFMS/v9-i1/5823.

26.Tarmidi, D., Fitria, G. N., and Ahmad, Z. (2019). Financial Performance and Audit Quality: Comparative Study of Investor Reaction. Scholars Bulletin, 5(12), pp. 825-830.

27.Waluyo. (2017). The Effect of Good Corporate Governance on Tax Avoidance: Empirical Study of The Indonesian Banking Company. The Accounting Journal of Binaniaga, 2(2), pp. 1-10.

28.Wijayani, D. R. (2016). Pengaruh Profitabilitas, Kepemilikan Keluarga, Corporate Governance, dan Kepemilikan Institusional terhadap Penghindaran Pajak di Indonesia (Studi Empiris Perusahaan Manufaktur yang Terdaftar di BEI tahun 2012-2014). Jurnal Dinamika Ekonomi \& Bisnis, 13(2), pp. 181 - 192. 
29.Wijayanti, Y. C., \& Merkusiwati, N. K. L. A. (2017). Pengaruh Proporsi Komisaris Independen, Kepemilikan Institusional, Leverage, dan Ukuran Perusahaan pada Penghindaran Pajak. E-Jurnal Akuntansi Universitas Udayana, 20(1), pp. 699-728.

30.Wiratmoko, S. (2018). The Effect of Corporate Governance, Corporate Social Responsibility, and Financial Performance on Tax Avoidance. The Indonesian Accounting Review, 8(2), pp. 245-257. 